\title{
THE SOCIETY OF CAPTIVES
}


PRINCETON UNIVERSITY PRESS

PRINCETON AND OXFORD 


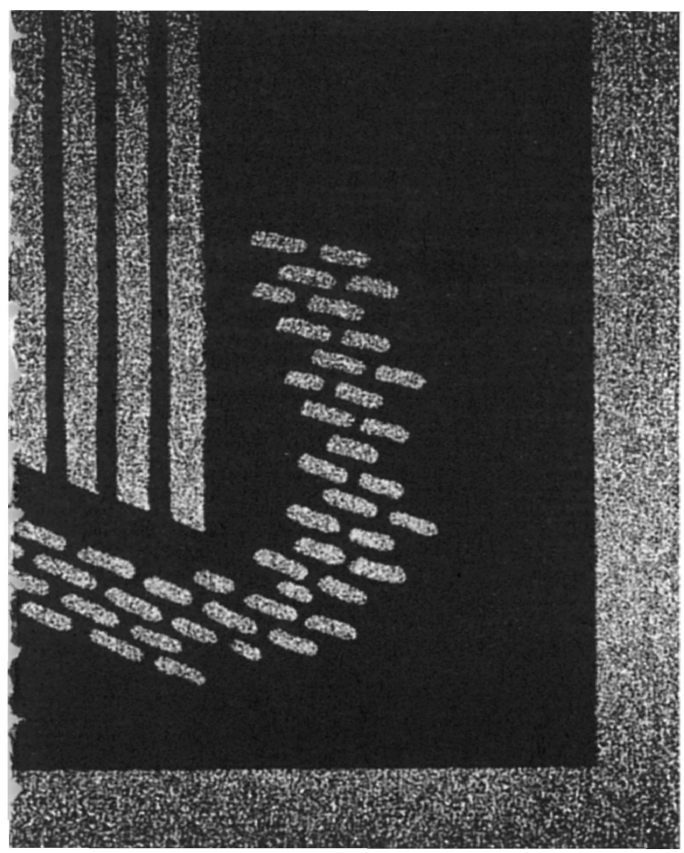

\section{THE SOCIETY OF CAPTIVES}

\section{A STUDY OF A}

MAXIMUM SECURITY PRISON

BY GRESHAM M. SYKES

With a new introduction by

Bruce Western and a new

epilogue by the author 
Copyright @ 1958, 2007 by Princeton University Press

Published by Princeton University Press, 41 William Street, Princeton, New Jersey 08540

In the United Kingdom: Princeton University Press, 3 Market

Place, Woodstock, Oxfordshire OX20 1SY

\section{All Rights Reserved}

First edition, 1958

First Princeton Classic Edition, with a new introduction by Bruce Western and a new epilogue by the author, 2007

Portions of the discussion concerning the corruption of the guard's authority are from Crime and Society, by Gresham M. Sykes.

Copyright 1956 by Random House, Inc. Reprinted by permission of Random House, Inc.

The material in the epilogue has been reprinted from Punishment and Social Control, 2d ed., Blomberg and Cohen, eds., pp.

357-365. Copyright @ 2003 Walter de Gruyter, Inc. Published by Aldine de Gruyter, Hawthorne, New York.

Library of Congress Cataloging-in-Publication Data

Sykes, Gresham M.

The society of captives : a study of a maximum security prison / by Gresham M. Sykes ; with a new introduction by Bruce Western and a new epilogue by the author. - 1st Princeton classic ed.

p. cm. - (Princeton classic editions)

Originally published, 1958.

Includes bibliographical references.

ISBN-13: 978-0-691-13064-4 (pb : alk. paper)

ISBN-10: 0-691-13064-7 (pb : alk. paper)

1. State Prison, Trenton (N.J.) 2. Prisons-New Jersey-

Case studies. 3. Prison administration-New Jersey-History.

4. Prisoners-New Jersey-Case studies. I. Title.

HV9475.N52T77 2007

$65^{\prime} .33-\mathrm{dc} 23$

2006052590

British Library Cataloging-in-Publication Data is available

Printed on acid-free paper. $\infty$

press.princeton.edu

Printed in the United States of America

1098765 
THIS BOOK IS DEDICATED TO THE MAN IN PRISONBOTH THE PRISONER AND HIS GUARD 
